\title{
Response of reindeer and caribou to human activities
}

\author{
Scott A. Wolfe, Brad Griffith \& \\ Carrie A. Gray Wolfe
}

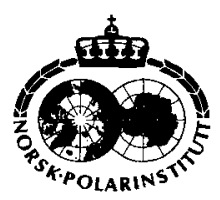

\begin{abstract}
Petroleum and mineral exploration and extraction, hydroelectric development, atmospheric transport of contaminants, timber harvesting and tourism are increasing worldwide, especially in the Arctic. This development may adversely affect populations of reindeer/caribou (Rangifer tarandus) which are the basis of subsistence economies for northern indigenous peoples. Our purpose is to present a survey of the literature that has investigated the response of reindeer/caribou to human activities. Individuals and groups of reindeer/caribou: 1) move away from point sources of disturbance; 2) increase activity and energy expenditure near disturbance; 3) delay crossing or fail to cross linear structures; 4) shift away from areas of extensive and intensive development; and 5) are killed by collisions with vehicles and by hunting along roads. Cows and calves during the calving season are the most easily disturbed group. Bulls in general and all reindeer/caribou during insect harassment are least likely to avoid development areas. Estimation of the proportion of a population that is exposed to disturbance and the implications of this exposure to annual energy budgets, survival and productivity of reindeer/caribou has received little attention. Future advances in understanding the implications of human disturbance to reindeer/ caribou will require cumulative effects assessment at annual, population and regional scales. Although some level of cumulative effect is likely, clear separation of cumulative effects of development from natural variation in caribou habitat use and demography will be difficult.
\end{abstract}

S. A. Wolfe, B. Griffith \& Carrie A. G. Wolfe, Institute of Arctic Biology, University of Alaska Fairbanks, Irving I Bldg., Fairbanks, AK 99775-7000, USA; B. Griffith also at USGS, Alaska Cooperative Fish and Wildife Research Unit, University of Alaska Fairbanks.

Caribou and reindeer are the most important subsistence and cultural resources for indigenous Arctic dwelling peoples (Burch 1972; Klein 1989) and are the subject of intense interest by people who view the Arctic as one of the last remaining wilderness regions. The welfare of Arctic reindeer/ caribou populations is a function of husbandry practices, climatic effects on habitats and anthropogenic forces within herd ranges (Kofinas et al. 2000). Advances in operation technology and discoveries of substantial reserves of petroleum and minerals in the Arctic have facilitated industrial development in the circumpolar region in the latter half of the 20th century (Klein 1980). Because many Arctic reindeer/caribou populations have had limited exposure to modern industrial development, there are potential implications of this development for reindeer/caribou movements, distribution and populations.

Sustainable development requires an understanding of the effects of development on wildlife populations and habitats. During the past 30 years many studies have investigated reindeer/caribou responses to human activities. This work has been periodically reviewed and synthesized (Klein 1971, 1980; Shideler 1986; Shideler et al. 1986; Cronin, Ballard, Truett et al. 1994; Cronin, Ballard, Bryan et al. 1998) but not all of these reviews are readily available. Our purpose in this paper is to survey the existing literature on the response of reindeer/caribou to human activities. We emphasize refereed research and synthesis publications. As much as possible, we restrict our presentation to reported results and avoid reiterat- 
ing interpretations of authors. Anecdotal observations and opinions are generally not reported. Internal reports often precede final publications; we concentrate on the latter.

The primary human activities that may affect reindeer/caribou include: 1) transportation corridors and associated traffic; 2) activities and infrastructures associated with petroleum, mineral, hydroelectric, forestry and recreational development; and 3) atmospheric transport of contaminants. Contaminant, hydroelectric development and surface alteration effects of human activities on reindeer/caribou are discussed elsewhere in this volume (Klein 2000). We focus on the remaining types of human activities and present results of our survey by type of disturbance, tabulate suggested mitigation measures and discuss the direction of future work.

\section{Transportation}

\section{Aircraft}

Caribou response (walking or running away) to aircraft (overflights, nearby landings) is variable depending on the season, degree of habituation, type of aircraft, altitude, airspeed, weather conditions, frequency of overflights, and the sex and age composition of caribou groups. Caribou reacted to small fixed-wing and helicopter overflights most strongly during calving (late May to early June), post-calving (early June to late June) and winter (Calef et al. 1976). Calves were most reactive, but cows did not abandon their calves even when aircraft passed directly overhead or landed nearby. Habituated caribou may be less reactive to aircraft. Caribou of the habituated Delta Herd, Alaska, ran from $36 \%$ of small single-engine aircraft overpasses in winter while non-habituated caribou of the Western Arctic Herd, Alaska, ran from $82 \%$ of small aircraft overpasses in winter (Davis et al. 1985; Valkenburg \& Davis 1985). Caribou were more responsive to helicopter than to small fixedwing overflights only at low $(<100 \mathrm{~m}$ above ground level [a.g.1.]) altitudes (McCourt et al. 1974), and response to both types of aircraft dissipated up through flight altitudes of 300$400 \mathrm{~m}$ a.g.l. (McCourt et al. 1974; Gunn \& Miller 1978) during calving and post-calving. Cows with calves and larger groups of caribou were more likely to respond to helicopter overflights than were other sex and age classes or smaller groups (Gunn \& Miller 1978; Miller \& Gunn 1980). However, there was no statistical difference in preand post-disturbance activity even though caribou tended to walk away from helicopter landing sites (Gunn et al. 1985).

Repeated exposure to low-level military jet overflights, especially during sensitive periods, may reduce calf survival and increase daily activity. The frequency of exposure of cows to low-level jet overflights during calving, immediate post-calving and summer (early July to midSeptember) explained $32 \%, 53 \%$ and $48 \%$ of the variance in calf survival, respectively (Harrington \& Veitch 1992). However, calf survival was not related to jet aircraft exposure during pre-calving, late-post calving and fall. During post-calving and insect harassment, caribou of the Delta Herd, Alaska, increased daily activity and reduced resting time when overflown by military jet aircraft at approximately $33 \mathrm{~m}$ a.g.l. (Maier 1996; Maier et al. 1998). However, neither Harrington \& Veitch (1992) nor Maier et al. (1998) found an increase in activity or distance travelled by caribou exposed to experimental jet overflights as low as $30 \mathrm{~m}$ a.g.l. during late winter.

An energetics model predicted that the weight of autumn body fat would decline by $0.07-0.41 \mathrm{~kg}$ in a year with favourable environmental conditions and would decline by $0.07-0.64 \mathrm{~kg}$ in a year with harsh environmental conditions if caribou were exposed to 10-40 consecutive days of single disturbance events by low-altitude jet overflights during post-calving (Luick et al. 1996). The highest frequency of exposure might reduce the probability of pregnancy the following year by 4 $5 \%$ under normal or poor environmental conditions, and severe insect harassment might exacerbate this effect. However, because only a small proportion of the population was likely to be exposed, jet aircraft exposure was unlikely to cause a substantial reduction in pregnancy rates (Luick et al. 1996).

\section{Roads, railways and infrastructures}

Effects of transportation corridors on reindeer/ caribou may be influenced by adjacent infrastructures, vehicle type, frequency of traffic, purpose of road use, habitat surrounding the roads, visual attributes of roads, habituation, sex and age of reindeer/caribou and season of use. Transportation corridors that provide access to, but are not part of, 
a primary development zone (e.g. Dalton Highway in Alaska, Dempster Highway in Canada) can contribute to effects of development on caribou.

The appearance of roads may influence caribou reaction. Elevated roads that present a visual barrier, roads that create a break in habitat in forested areas, or roads with adjacent snow berms or habitat that obscured vision were most strongly avoided by caribou in fall and winter (Surrendi \& DeBock 1976). On calving grounds, caribou were deflected by pipeline berms greater than $1.5 \mathrm{~m}$ above ground level because berms presumably served as visual barriers (Hanson 1981).

Heavy traffic may accentuate the reaction of reindeer/caribou to roads and railways, impede crossings and serve as barriers, result in substantial mortality from collisions and hunters, and increase vigilance behaviour that may reduce foraging efficiency (Skoog 1968; Klein 1971; Villma 1975; Surrendi \& DeBock 1976; Roby 1978; Koskela \& Nieminen 1983; Skrobov 1984). Substantial mortality and disruption of reindeer movements by railways in the Arkangelsk and Taimyr development regions of Russia was summarized by Klein (1971). Very high rates of traffic ( $\geq 1$ vehicle/min) probably create a barrier to caribou movements (Murphy 1988), but caribou may avoid heavy traffic and hunters by crossing roads at night (Skoog 1968; Surrendi \& DeBock 1976). Harassment by insects, especially oestrid flies (warble flies and nose bot flies), increases the propensity of all sex and age classes to cross roads and infrastructures (Child 1973; Smith \& Cameron 1983; Murphy \& Curatolo 1987; Murphy 1988; Pollard et al. 1996; Noel et al. 1998).

In contrast, infrequently travelled transportation corridors resulted in low numbers of road-kills, did not deter road crossing by caribou, and had no observable effect on traditional migration routes, annual distribution or energetic costs (Klein 1971; Johnson \& Todd 1977; Johnson 1985; Russell \& Martell 1985). Traditional migrations have continued across constructed railways or roads in Newfoundland (Bergerud 1971), Yukon (Surrendi \& DeBock 1976; Russell \& Martell 1985), British Columbia (Johnson \& Todd 1977) and Alaska (Skoog 1968), but have ceased after construction of a railway and highway between summer and winter ranges in Norway (Nellemann et al. 2000).

Cows with calves in spring and summer were more reactive to infrastructures than bulls (Roby 1978; Cameron 1983; Smith \& Cameron 1983; Whitten \& Cameron 1983; Dau \& Cameron 1986;
Klein 1991; Cameron, Reed et al. 1992; Cronin, Ballard, Truett et al. 1994; Nellemann \& Cameron 1996, 1998). Cow caribou distribution shifted away from pipelines, roads and associated traffic during calving (Cameron \& Whitten 1979; Dau \& Cameron 1986; Lawhead 1988; Cameron, Reed et al. 1992) even though vehicular traffic on the study area road was limited (100-200 vehicles/day) (Cameron, Reed et al. 1992). Mean densities of calving caribou were 2-18 times higher outside the primary development area of the Prudhoe Bay oil field, Alaska (Whitten \& Cameron 1985). Few caribou were present in a zone within $3-5 \mathrm{~km}$ of roads during calving, and movements were deflected or delayed near human activity (Lawhead 1988). With construction of an oil field access road through a calving concentration area, mean caribou density decreased $78 \%$ within $1 \mathrm{~km}$ of roads and concurrently increased $321 \%$ in areas 5-6 km from roads (Cameron, Reed et al. 1992). Thus, the footprint of infrastructure, in terms of avoidance by calving cows, extended $5-6 \mathrm{~km}$ outward from the actual infrastructure (Cameron, Reed et al. 1992). Further, caribou density at calving was inversely related to road density, declining by $63 \%$ from baseline densities when there was $>0.3 \mathrm{~km}$ road $/ \mathrm{km}^{2}$ and declining by $86 \%$ from baseline densities when there was $>0.9 \mathrm{~km} \mathrm{road} / \mathrm{km}^{2}$ (Nellemann \& Cameron 1998). Avoidance of roads was accentuated in otherwise preferred foraging terrain (Nellemann \& Cameron 1996).

In spring and fall, designated game crossings, sag bends and buried pipeline sections were used by $29 \%$ of caribou crossing the Trans-Alaska Pipeline System (TAPS) but other structures were used little because they were outside major caribou crossing zones (Carruthers \& Jakimchuk 1987). Caribou crossed under pipes with heights ranging 1-5.3 m (Carruthers \& Jakimchuk 1987) but preferred buried sections of pipeline and pipes elevated $>2.4 \mathrm{~m}$ compared to those elevated $<2.1 \mathrm{~m}$ for winter crossing of TAPS (Eide et al. 1986). During migration, caribou followed cleared seismic lines in taiga when these clearings were parallel to migration routes. However, when the clearings were perpendicular to migration routes, caribou were usually deflected or delayed (Banfield 1974).

Most (77-85\%) caribou avoided experimental pipeline structures on the calving ground in summer (Child 1973). Ramps were used most frequently $(17.6 \%)$, and $76 \%$ of caribou that 
crossed successfully used ramps rather than pipeline underpasses. Individuals were more likely to cross successfully $(62 \%)$ than were groups of 2 1500 animals (24\%) and only $8 \%$ of groups larger than 10 animals crossed successfully. Groups led by cows were more likely to cross $(38.3 \%)$ than were groups led by bulls ( $8 \%$ ). Crossing success was greatest during periods of insect harassment, and insect harassment was a more important influence on crossing success than season or habituation to experimental crossing structures (Child 1973).

Once oil fields were operational, caribou selected buried sections of pipeline as crossings more often than expected (Curatolo \& Murphy 1986). In contrast to earlier experimental work (Child 1973), Curatolo \& Murphy found no difference between cow-calf and bull groups in the percentage of successful pipeline crossings by Central Arctic caribou. Child's work was conducted early in the industrial development of Prudhoe Bay when caribou had little or no experience with infrastructures, while Curatolo \& Murphy's work was conducted after caribou had been exposed to industrial development for at least a decade. In agreement with Child's experimental work, Curatolo \& Murphy found that large groups of caribou tended to cross pipelines less successfully than small groups.

Group size, insect harassment and the combination of roads and traffic levels paralleling pipelines may interact to affect pipeline-crossing success by caribou. Crossing frequency was lowest where the road was adjacent to a pipeline and traffic was highest (15 vehicles/hour) (Curatolo 1983; Curatolo \& Murphy 1986). Elevated pipelines that closely paralleled roads with high traffic levels reduced crossing success and increased movement rates (Murphy 1988) by caribou. Insect harassment may have caused caribou to form larger groups (Murphy 1988; Pollard et al. 1996; Noel et al. 1998), these groups may have contained easily disturbed individuals, and these reactive individuals may have reduced crossing success of the larger groups (Smith \& Cameron 1983; Curatolo \& Murphy 1986). Probably because larger groups of caribou took longer to cross pipelines and roads and the likelihood of vehicular traffic increased with time, crossing success was significantly reduced by $55 \%$ when roads paralleled elevated pipelines and there was no insect harassment or there was mosquito harassment only (Curatolo \& Murphy 1986). However, when caribou were harassed by oestrid flies, road/pipe combinations did not reduce crossing success (Smith \& Cameron 1983; Murphy 1988). Both insect harassment and elevated pipelines that paralleled roads with traffic reduced the time that caribou spent lying and increased the time spent moving (Fancy 1983; Murphy \& Curatolo 1987). Insect harassment, but not oil field disturbance, reduced the time caribou spent feeding (Murphy \& Curatolo 1987).

During insect harassment, caribou used oil field gravel pads and shade provided by elevated production facilities, regardless of sex and age composition of the group (Truett et al. 1994; Pollard et al. 1996; Noel et al. 1998). Wind speeds were higher on gravel pads, and mosquitoes were more abundant on tundra than on active or inactive gravel pads (Pollard et al. 1996). When disturbed by humans or vehicles, caribou using gravel pads during insect harassment usually responded by shifting position on the pads (Noel et al. 1998).

Caribou traversed oil fields during insect harassment and this activity was highly variable and changed within hours (Pollard et al. 1996). More caribou were observed within the Prudhoe Bay oil field when insect activity was moderate to high than when insect activity was low (Pollard et al. 1996). Cronin, Amstrup et al. (1998) found no relationship between caribou distribution and distance from oil field infrastructure during the entire post-calving period for the Central Arctic Herd. However, Cameron, Lenart et al. (1995) noted decreased east-west movements of radiocollared caribou through the most intensively developed portion of the Prudhoe Bay oil field during insect harassment.

\section{Recreational activities}

Exposure to recreational activities may result in increased vigilance, avoidance behaviour and redistribution of caribou. Tyler (1991) found that reindeer that were experimentally approached by snowmobiles in Scandinavia first reacted at a distance of $640 \mathrm{~m}$, were disturbed at a distance of $410 \mathrm{~m}$, fled at a distance of $80 \mathrm{~m}$, and travelled $160 \mathrm{~m}$ in 22 seconds after disturbance in winter. Individual disturbance events had negligible effects on the daily energy budgets of reindeer (Tyler 1991). Severe or prolonged disturbance (herding) of reindeer by snowmobiles could lead to exhaustion (Muller-Wille 1975) or cause panic 
among animals (Klein 1971). Caribou may avoid areas where hunters pursue them on snowmobiles (Smith 1988). In Denali National Park, Alaska, the frequency of strong reactions by caribou to tourist buses increased as the disturbance escalated from a drive by, to a stop with quiet bus occupants, to a stop with noisy bus passengers or passengers departing from the bus (Tracy 1977). The number of severe reactions nearly doubled when people unloaded from buses in Denali National Park (Dean \& Tracy 1979). Caribou in Denali reacted less severely to tour bus traffic with increasing distance from roads; $60 \%$ and $10 \%$ of caribou reacted visually to traffic $\leq 100 \mathrm{~m}$ and $>400 \mathrm{~m}$, respectively (Dean \& Tracy 1979). Reindeer avoided an area within $5 \mathrm{~km}$ of a tourist resort in Norway in March (Nellemann et al. 2000)-and similar avoidance has been observed during winter (Helle \& Sarkela 1993) and spring (Vistness 1999).

\section{Forestry}

Timber harvest and post-harvest management may directly and indirectly affect winter habitats of Arctic calving reindeer/caribou. Selective harvest of merchantable trees and snags removed 30-55\% of available lichens (Armleder \& Stevenson 1996). Although live biomass of arboreal lichen on remaining trees increased in partial-cut forests (Rominger et al. 1994), the total number of trees per hectare and overall availability of lichen biomass decreased. After clear-cutting, natural lichen regeneration only occurred within $350 \mathrm{~m}$ of mature forest with high lichen abundance (Stevenson 1990). Post-harvest burning denuded lichen cover for long periods, even though growth of higher plants may have increased (Eriksson 1975). After clear-cutting, caribou moved away from clear-cut areas, selected mature black-spruce forest, and avoided burned areas and hardwood forests (Chubbs et al. 1993). Conflicts between forestry and caribou habitat will likely be most pronounced in lichen-moss habitat types where caribou winter range and high quality timber production overlap (Cichowski 1996).

Recently harvested forests are often fertilized to enhance regeneration. In winter, cratering through snow for forage by reindeer in Sweden was reduced by $50-85 \%$ for one year in $50 \times 50 \mathrm{~m}$ plots fertilized with ammonium nitrate compared to unfertilized plots; moreover, cratering was reduced by $90-95 \%$ for two years in plots fertilized with urea (Eriksson 1980). Domestic reindeer refused to eat wood fertilizers with no other food supplement, preferred to eat pure lichen over lichen containing fertilizers, and ate significant amounts of fertilized lichen only when no other forage was available (Rajala \& Westerling 1980). Artificial dosages of $1.0 \mathrm{~g}^{-} \mathrm{NO}_{3} / \mathrm{kg}$ body weight and $0.4 \mathrm{~g}^{-} \mathrm{NO}_{3} / \mathrm{kg}$ body weight were lethal and chronically toxic, respectively, when administered through stomach tubes in 5 or $10 \%$ aqueous solution. However, reindeer in good condition were more resistant to dosages of ${ }^{-} \mathrm{NO}_{3}$ than reindeer in poor condition. Although fertilizers may reduce feeding by reindeer, they are unlikely to reach lethal or toxic levels when correctly applied (Nordkvist \& Erne 1983).

\section{Mitigation measures}

Mitigation measures emphasize conducting research and planning before development, minimizing disturbance of reindeer/caribou during critical stages of their life history, providing free access to important habitats, preserving the value of important habitats and minimizing direct mortalities (Table 1). Although these mitigation measures have been good faith attempts to minimize caribou disturbance and redistribution, the population level effectiveness of mitigation has not been adequately assessed.

\section{Discussion}

It is clear that reindeer/caribou may respond negatively to human activity, vehicles and aircraft, roads and railways, and industrial development infrastructures. In addition, timber harvesting, linear transportation, and infrastructure corridors may fragment or degrade habitats. Overt behavioural responses can result in elevated energy requirements for individuals and redistribution of animals. Cows during calving, and larger $(>10)$ groups, are most susceptible to these effects. The behavioural effect is positively related to the novelty, intensity and spatial extent of the disturbance, but may be reduced or eliminated during periods of environmental stress such as harassment by insects. 
- Involve biologists in project design.

- Minimize traffic and prohibit unnecessary access in and near oil fields, especially in critical habitats and seasons.

- Avoid construction and exploration during calving and postcalving.

- Limit surface development and minimize the "network" effect of road development.

- Make road berms $<1.2 \mathrm{~m}$ above ground level, elevate pipes $\geq 1.5 \mathrm{~m}$ a.g.l. from the bottom, bury pipes where feasible.

- Maintain passage sites for pipeline or other infrastructures at known caribou crossing areas.

- Separate elevated pipelines from roads, especially heavily travelled roads, by $\geq 150 \mathrm{~m}$

- Use monitoring personnel to minimize exposure of caribou.

- Revegetate scarred lands.

- Avoid multiple passes of tracked vehicles in sensitive vegetation types.

- Restrict hunting from service roads in and near industrial complexes.

- Avoid low-level aircraft overflights of concentration areas, especially during calving and post-calving.

- Restrict overflight altitudes to $>150 \mathrm{~m}$ a.g.l. in spring and fall and to $>300 \mathrm{~m}$ a.g.l. during calving.

- Create development-free sanctuaries and special harvest management strategies in areas where developments were poorly designed.
- Klein 1980; Cronin, Ballard, Truett et al. 1994.

- Murphy 1988; Cronin, Ballard, Truett et al. 1994; Cameron, Lenart et al. 1995.

- Jingfors et al. 1983; Cronin, Ballard, Truett et al. 1994.

- Smith et al. 1994; Nellemann \& Cameron 1998.

- Hanson 1981; Lawhead 1988; Curatolo \& Murphy 1986; Eide 1986; Murphy \& Curatolo 1987.

- Child 1973; Eide 1986; Skrobov 1984; Curatolo \& Murphy 1986; Murphy \& Curatolo 1987.

- Curatolo \& Murphy 1986; Murphy \& Curatolo 1987; Murphy 1988; Cronin, Ballard, Truett et al. 1994.

- Cronin, Ballard, Truett et al. 1994.

- Jorgenson \& Joyce 1994.

- Raynolds \& Felix 1989

- Cronin, Ballard, Truett et al. 1994.

- Calef et al. 1976; Harrington 1991; Harrington \& Veitch 1992; Maier et al. 1998.

- Calef et al. 1976; McCourt et al. 1974; Calef et al. 1976; Gunn \& Miller 1978; Cronin, Ballard, Truett et al. 1994

- Syroechkovskii 1984; Sokol'skii 1984; Syroechkovskii 1990; Shtil'mark 1984; Shtil'mark \& Azarov 1984.
The population level effects of disturbance on reindeer/caribou are less clear. Reduced density of reindeer/caribou near disturbance suggests that individual avoidance of disturbance accumulates at the population level. However, the quantitative implications of redistribution in terms of access to forage, exposure to other threats (e.g. predation, hunting), or population performance have not been adequately addressed. Although animals may move to less desirable habitat, studies necessary to demonstrate that displacement habitat does not meet requirements have not been conducted. The current discussion largely assumes that a negative behavioural response by individuals implies a negative numerical response by the population. Whether a numerical response follows a behavioural response will depend on the quantity, quality and accessibility of alternate habitats in relation to animal requirements.

Estimation of the net effect of disturbance on caribou will require quantitative assessment of the cumulative effects of disturbance. Cumulative effects are the changes in population performance (e.g. demography, size and distribution) that accrue as the sum or product of individual disturbance events (Spaling \& Smit 1993, 1995). Cumulative costs will be a function of the intensity and frequency of disturbance events, the proportion of the population that is exposed to disturbance, the location and temporal persistence of disturbance and the suite of disturbances that impinge on individuals across seasonal ranges. Ideally, clear cause-effect relationships between disturbance and reindeer/caribou performance should be established (Boyle et al. 1997) but the nature of industrial development and wide-ranging behaviour of reindeer/caribou precludes rigorous field experimentation. Reliance on robust correlations and off site experimental testing of key cause-effect mechanisms will be required.

Disturbance effects may accumulate both spatially and temporally (Spaling \& Smit 1995), and result from additive individual events of the same nature, or from interactive and multiple events of different natures (Spaling \& Smit 1993). Thus, disturbance events that are individually inconse- 
quential to population performance may accumulate across animals, space and time in a simple or complex manner and be expressed at the population level. Expression of cumulative effects may not coincide in space or time with a particular disturbance. For example, small changes in proportional intake of forages of varying digestibility during calving and post-calving may have major effects on net diet quality (White 1983) and influence summer weight gain. Reduced weight gain on summer ranges may be expressed as reduced parturition rates in the following spring (Cameron \& Ver Hoef 1994) or as elevated mortality rates in winter (White 1992).

Cumulative effects must be of consistent direction and exceed natural variability within or among herds to be detectable. For example, a 3$5 \%$ cumulative reduction in parturition or calf survival would be difficult to demonstrate in a system where parturition or calf survival normally varied by $15 \%$ among years (Walsh et al. 1995). Small individual or cumulative effects on energy expenditure, parturition or survival that may have biological significance to population trajectory are unlikely to be statistically detectable unless a substantial proportion of the population is monitored (Walsh et al. 1995). Caribou inhabit highly variable environments and their populations fluctuate dramatically at decadal scales for reasons that are not well understood. Thus, assessment of cumulative effects solely on the basis of population level is ill-advised without an understanding of the mechanisms that drive population performance. Confounding variables may either mask or enhance the appearance of cumulative disturbance effects.

Natural system variability may influence not only the detectability but also the level of effect of disturbance on reindeer/caribou. The primary effect of disturbance may be to increase variability in distribution and population performance rather than to alter mean values. Variance is the most important determinant of population persistence (Leigh 1981) and natural and anthropogenic variance will have both temporal and spatial components.

Annual or seasonal variance in environmental conditions may affect the local expression of disturbance on reindeer/caribou. Many studies of the effects of human activity on caribou have been conducted during the recent period of global warming. During this warming, the trend in spring/summer environmental conditions (Myneni et al. 1998) has been quite variable among Arctic reindeer/caribou ranges. This has two potential implications. First, any individual or population level costs of disturbance are proportionally less important when local environmental conditions are favourable. If requirements are exceeded, an energetic or performance cost may be accommodated. Conversely, favourable environmental conditions may accentuate behavioural avoidance of disturbance by reindeer/caribou if the availability of adequate alternate habitats is enhanced. Under less favourable environmental conditions, suitable alternate habitats may not be available and avoidance of disturbance may be less likely. From a seasonal perspective, caribou use of the Prudhoe Bay oil field during periods of insect harassment - (Pollard et al. 1996) is an example of this latter phenomenon.

Spatial variance in environmental conditions may affect the expression and detectability of disturbance on reindeer/caribou as well. All herds should not be expected to show similar sensitivity. Herds that occupy low quality or more variable ranges, or those that are exposed to multiple types of disturbance in several portions of their annual ranges, may be less resilient to disturbance. For example, the population size of the Porcupine Caribou Herd, which calves in north-eastern Alaska, has never increased at more than an approximate 5\% annual rate (Walsh et al. 1995) and since 1989 has declined by approximately 5\% annually. During the same period the population sizes of the other three Arctic calving herds in Alaska (Central Arctic, Teshekpuk Lake, Western Arctic) have grown at rates approximating $10 \%$. A similar population cost of disturbance (e.g. $2 \%$ reduction in growth rate) would be expected to have a proportionately greater effect on the Porcupine Herd than on any of the other three Alaskan herds.

Unfortunately, quantitative estimates of the exposure rate of individuals or of the proportions of populations that are exposed to human activities are lacking. Thus, modelled estimates of energetic costs of hypothetical cumulative exposure at the individual level (Luick et al. 1996; Bradshaw et al. 1997, 1998) cannot be quantitatively projected to the population. To obtain estimates of cumulative population exposure, substantially more use of satellite and conventional radio-telemetry on an adequate and representative sample of individuals in potentially affected populations will be required. Estimates of productivity will continue to 
require field-based sampling. Remote sensing of habitats may provide the opportunity to monitor long-term trends in background habitat conditions and help partition the effects of habitat and disturbance on population performance.

A useful interim approach will be to establish habitat-demography relationships in undisturbed systems that have adequate data, and use these relationships as tools to hypothesize the implications of disturbance to reindeer/caribou in disturbed systems. Monitoring systems can then be designed to test these hypotheses. Currently, little is known of the relative importance of forage availability, human harvest or natural predation on long-term population sizes of Arctic caribou herds. In remote Arctic systems, often all that is routinely and rigorously monitored is population size. More studies of habitat-demography relationships are needed to elucidate the mechanisms of interaction and to assess the relative value of habitats.

Substantially more empirical and modelling work needs to be conducted before the effect of human activity on caribou populations can be understood and predicted. Studies that identify the mechanisms of cumulative population response, estimate exposure of individuals and populations, and model population response of reindeer/caribou to human activity are the most neglected and needed future endeavours. In the interim, the prudent course of action is to avoid unnecessary disruption of natural patterns of landscape use by reindeer/caribou, to effectively plan and implement mitigation procedures in development areas, and to closely monitor the effectiveness of existing mitigation techniques.

Acknowledgements. - This work was funded by the Canadian Environment and Renewable Resources Directorate, Northern Affairs Program, Department of Indian Affairs and Northern Development, and by National Science Foundation Grant OPP-9521459. We thank S. A. Kalff and D. E. Russell for their facilitation of this work. A. Gunn, D. R. Klein, F. A. Servello and R. T. Shideler provided constructive comments on early versions of this paper.

\section{References}

Armleder, H. M. \& Stevenson, S. K. 1996: Using alternative silvicultural systems to integrate mountain caribou and timber management in British Columbia. Rangifer, Spec. Issue 9, 141-148.

Banfield, A. W. 1974: The relationship of caribou migration behavior to pipeline construction. In V. Geist \& F. Walther (eds.): The behavior of ungulates and its relation to management. Vol. 2. IUCN New Ser. 24, 797-804. Morges, Switzerland. Int. Union for the Conservation of Nature.

Bergerud, A. T. 1971: The population dynamics of Newfoundland caribou. Wildl. Monogr. 25, 1-25.

Boyle, J. R. and 12 others. 1997: Cumulative effects of forestry practices: an example framework for evaluation from Oregon, U.S.A. Biomass and Bioenergy 13, 223-245.

Bradshaw, C. J. A., Boutin, S. \& Hebert, D. M. 1997: Effects of petroleum exploration on woodland caribou in northeastern Alberta. J. Wildl. Manage. 61, 1127-1133.

Bradshaw, C. J. A., Boutin, S. \& Hebert, D. M. 1998: Energetic implications of disturbance caused by petroleum exploration to woodland caribou. Can. J. Zool. 76, 1319-1324.

Burch, E. S., Jr. 1972: The caribou/wild reindeer as a human resource. Amer. Antiq. 37, 337-368.

Burkes, F. 1988: The intrinsic difficulty of predicting impacts: lessons from the James Bay hydro project. Environ. Impact Assess. Rev. 8, 201-220.

Calef, G. W., DeBock, E. A. \& Lortie, G. M. 1976: The reaction of barren-ground caribou to aircraft. Arctic 29, 201-212.

Cameron, R. D. 1983: Issue: caribou and petroleum development in Arctic Alaska. Arctic 36, 227-231.

Cameron, R. D., Lenart, E. A., Reed, D. J., Whitten, K. R. \& Smith, W. T. 1995: Abundance and movements of caribou in the oilfield complex near Prudoe Bay, Alaska. Rangifer 15, 3-7.

Cameron, R. D., Reed, D. J., Dau, J. R. \& Smith, W. T. 1992: Redistribution of calving caribou in response to oil field development on the Arctic Slope of Alaska. Arctic 45, 338 342.

Cameron, R. D. \& Ver Hoef, J. 1994; Predicting parturition rate of caribou from autumn body mass. J. Wildl. Manage. 58, 674-678.

Cameron, R. D. \& Whitten, K. R. 1979: Seasonal movements and sexual segregation of caribou determined by aerial survey. J. Wildl. Manage. 43, 626-633.

Carruthers, D. E. \& Jakimchuk, R. D. 1987: Migratory movements of the Nelchina Caribou Herd in relation to the Trans-Alaska pipeline. Wildl. Soc. Bull. 15, 414-420.

Child, K. N. 1973: The reactions of barren ground caribou (Rangifer tarandus granti) to simulated pipeline and pipeline crossing structures at Prudhoe Bay, Alaska. Completion report to Alaska Pipeline Serv. Co. Alaska Cooperative Wildlife Research Unit, Univ. of Alaska, Fairbanks.

Chubbs, T. E., Keith, L. B., Mahoney, S. P. \& McGrath, M. J. 1993: Responses of woodland caribou (Rangifer tarandus caribou) to clear-cutting in east-central Newfoundland. Can. J. Zool. 71, 487-493.

Cichowski, D. B. 1996: Managing woodland caribou in westcentral British Columbia. Rangifer, Spec. Issue 9, 119-126.

Cronin, M. A., Amstrup, S. C., Durner, G. M., Noel, L. E., McDonald, T. L. \& Ballard, W. B. 1998: Caribou distribution during the post-calving period in relation to infrastructure in the Prudhoe Bay oil field, Alaska. Arctic 51, 85-93.

Cronin, M. A., Ballard, W. B., Bryan, J. D., Pierson, B. J. \& McKendrick, J. D. 1998: Northern Alaska oil fields and caribou: a commentary. Biol. Conserv. 83, 195-208.

Cronin, M. A., Ballard, W. B., Truett, J. \& Pollard, R. 1994: Mitigation of the effects of oil field development and transportation corridors on caribou. Final report for the Alaska Caribou Steering Committee. LGL Alaska Research Associates, Inc. Anchorage.

Curatolo, J. 1983: Caribou response to the pipeline/road complex in the Kuparuk oil field, Alaska. In A. M. Martell 
\& D. E. Russell (eds): Caribou and human activity Proceedings of the First North American Caribou Workshop, Whitehorse, Y.T., 1983. Pp. 62. Ottawa: Canadian Wildlife Service.

Curatolo. J. A. \& Murphy, S. M. 1986: The effects of pipelines, roads, and traffic on the movements of caribou, Rangifer tarandus. Can. Field-Nat. I00, 218-224.

Dau, J. R. \& Cameron, R. D. 1986: Effects of a road system on caribou distribution during calving. Rangifer, Spec. Issue I, 95-101.

Davis, J. L., Valkenburg, P. \& Boertje, R. D. 1985: Disturbance and the Delta Caribou Herd. In A. M. Martell \& D. E. Russell (eds.): Caribou and human activity. Proceedings of the First North American Caribou Workshop, Whitehorse, Y.T., 1983. Pp. 2-6. Ottawa: Canadian Wildlife Service.

Dean, F. C. \& Tracy, D. M. 1979: McKinley's shuttle bus system and the management of traffic impact upon wildlife. In R. Ittner et al. (eds.): Recreational Impact on Wildlands Conference proceedings. US Forest Service no. R-6-00I1979. Pp. 263-270. Seattle, WA.

Eide, S. H., Miller, S. D. \& Chihuly, M. A. 1986: Oil pipeline crossing sites utilized in winter by moose, Alces alces, and caribou, Rangifer tarandus, in southcentral Alaska. Can. Field-Nat. 100, 197-207.

Eriksson, O. 1975: Silvicultural practices and reindeer grazing in Northern Sweden. In Luick et al. (eds.): Proceedings of the First International Reindeer/Caribou Symposium, Fairbanks, Alaska, 1972. Biol. Pap. Univ. Alaska, Spec. Rep. I, 108-112.

Eriksson, O. 1980: Effects of forest fertilization on the cratering intensity of reindeer. In E. Reimers et al. (eds.): Proceedings of the Second International Reindeer/Caribou Symposium, Roros, Norway, 1979. Pp. 26-40. Trondheim: Direktorat for Vilt og Ferskvannsfisk (Directorate of Game and Freshwater Fish).

Fancy, S. G. 1983: Movements and activity budgets of caribou near oil drilling sites in the Sagavanirktok River floodplain, Alaska. Arctic 36, 193-197.

Gunn, A. \& Miller, F. L. 1978: Caribou and muskoxen response to helicopter harrassment, Prince of Wales Island, 1976-77. ESCOM no. AI-30. Canadian Wildlife Service, Fisheries and Environment Canada.

Gunn, A., Miller, F. L., Glaholt, R. \& Jingfors, K. 1985: Behavioral responses of barren-ground caribou cows and calves to helicopters on the Beverly Herd calving grounds, Northwest Territories. In A. M. Martell \& D. E. Russell (eds.): Caribou and human activity. Proceedings of the First North American Caribou Workshop, Whitehorse, Y.T., 1983. Pp. 10-14. Ottawa: Canadian Wildlife Service.

Hanson, W. C. 1981: Caribou (Rangifer tarandus) encounters with pipelines in northern Alaska. Can. Field-Nat. 95, 57-62.

Harrington, F. H. 1991: Short-term impacts of low-level jet fighter training on caribou in Labrador. Arctic 44, 318-327.

Harrington, F. H. \& Veitch, A. M. 1992: Calving success of woodland caribou exposed to low-level jet fighter overflights. Arctic 45, 213-218.

Helle, T. \& Sarkela, M. 1993: The effects of outdoor recreation on range use by semi-domesticated reindeer. Scand. J. For. Res. 8, 123-133.

Jingfors, K., Gunn, A. \& Miller, F. L. 1983: Caribou disturbance research on the Beverly calving grounds, Northwest Territories, Canada. Acta Zool. Fenn. 175, 127-128.

Johnson, D. R. 1985; Man-caused deaths of mountain caribou, Rangifer tarandus, in southeastern British Columbia. Can. Field-Nat. 99, 542-544.
Johnson, D. R. \& Todd, M. C. 1977: Summer use of a highway crossing by mountain caribou. Can. Field-Nat. 91, 312-314. Jorgenson, M. T. \& Joyce, M. R. 1994: 6 strategies for rehabilitating land disturbed by oil development in Arctic Alaska. Arctic 47, 374 390.

Klein, D. R. 1971: Reaction of reindeer to obstructions and disturbances. Science 173, 393-398.

Klein, D. R. 1980: Reaction of caribou and reindeer to obstructions: a reassessment. In E. Reimers et al. (eds.): Proceedings of the Second International Reindeer/Caribou Symposium, Røros, Norway, 1979. Pp. 519-526. Trondheim: Direktorat for Vilt og Ferskvannsfisk (Directorate of Game and Freshwater Fish).

Klein, D. R. 1989: Northern subsistence hunting economies. In R. J. Hudson et al. (eds.): Wildlife production systems: economic utilisution of wild ungulates. Pp. 96-111. Cambridge: Cambridge University Press.

Klein, D. R. 1991: Caribou in the changing North. Appl. Anim. Behav. Sci. 29, 279-291.

Klein, D. R. 2000: Arctic grazing systems and industrial development: can we minimize conflicts? Polar Res. 19(l), 91-98.

Kofinas, G., Osherenko, G., Klein, D. \& Forbes, B. 2000: Research planning in the face of change: the human role in reindeer/caribou systems. Polar Res. 19(1), 3-21.

Koskela, K. \& Nieminen, M. 1983: Death among reindeer caused by traffic in Finland during 1976-80. Acta Zool. Fenn. 175. 163.

Lawhead, B. E. 1988: Distribution and movements of Central Arctic Herd caribou during the calving and insect seasons. Proceedings of the Third North American Caribou Workshop. Wildl. Tech. Bull. 8, 8-13. Alaska Dept. of Fish and Game.

Leigh, E. G., Jr. 1981: The average lifetime of a population in a varying environment. $J$. Theor. Biol. 90, 213-239.

Luick, B. R., Kitchens, J. A., White, R. G. \& Murphy, S. M 1996: Modeling energy and reproductive costs in caribou exposed to low flying military jet aircraft. Rangifer, Spec. Issue 9, 209-212.

Maier, J. A. K. 1996: Ecological and physiological aspects of caribou activity and responses to aircraft overflights. Ph.D. diss., University of Alaska Fairbanks.

Maier, J. A. K., Murphy, S. M., White, R. G. \& Smith, M. D. 1998: Responses of caribou to overflights by low-altitude jet aircraft. J. Wildl. Manage. 62, 752-766.

McCourt, K. H., Feist, J. D., Doll, D. \& Russell, J. J. 1974: Disturbance studies of caribou and other mammals in the Yukon and Alaska, 1972. Biol. Rep. Ser. 5. Renewable Resources Consulting Services Ltd.

Miller, F. L. \& Gunn, A. 1980: Responses of Peary caribou cowcalf pairs to helicopter harassment in the Canadian high Arctic. In E. Reimers et al. (eds.): Proceedings of the Second International Reindeer/Caribou Symposium, Roros, Norway, 1979. Pp. 497-507. Trondheim: Direktorat for Vilt og Ferskvannsfisk (Directorate of Game and Freshwater Fish).

Muller-Wille, L. 1975: Changes in Lappish reindeer herding in northern Finland caused by mechanization and motorization. In Luick et al. (eds.): Proceedings of the First International Reindeer/Caribou Symposium, Fairbanks, Alaska, 1972. Biol. Pap. Univ. Alaska, Spec. Rep. I, 122-126.

Murphy, S. M. 1988: Caribou behavior and movements in the Kuparuk Oilfield: implications for energetic and impact analyses. Wildl. Tech. Bull. 8, 196-209. Alaska Dept. Fish \& Game. 
Murphy, S. M. \& Curatolo, J. A. 1987: Activity budgets and movement rates of caribou encountering pipelines, roads, and traffic in northern Alaska. Can. J. Zool. 65, 2483-2490.

Myneni, R. B., Tucker, C. J., Asrar, G. \& Keeling, C. D. 1998: Interannual variations in satellite-based vegetation index data from 1981 to 1991. J. Geophys. Res. 103,6145-6160.

Nellemann, C. \& Cameron, R. D. 1996: Effects of petroleum development on terrain preferences of calving caribou. Arctic $49,23-28$

Nellemann, C. \& Cameron, R. D. 1998: Cumulative impacts of an evolving oil-field complex on the distribution of calving caribou. Can. J. Zool. 76, 1425-1430.

Nellemann, C., Jordhoy, P., Stoen, O. \& Strand, O. 2000: Cumulative impacts of tourist resorts on wild reindeer (Rangifer tarandus tarandus) during winter. Arctic 53, 9-17.

Noel, L. E., Pollard, R. H., Ballard, W. B. \& Cronin, M. A. 1998: Activity and use of active gravel pads and tundra by caribou, Rangifer tarandus granti, within the Prudhoe Bay oil field, Alaska. Can. Field-Nat. 112, 400-409.

Nordkvist, M. \& Eme K. 1983: The toxicity of forest fertilizers (ammonium nitrate) to reindeer. Acta Zool. Fenn. 175, 101e105.

Pollard, R. H., Ballard, W. B., Noel, L. E. \& Cronin, M. A. 1996: Parasitic insect abundance and microclimate of gravel pads and tundra within the Prudhoe Bay oil field, Alaska, in relation to use by caribou, Rangifer tarandus granti. Can. Field-Nat. 110, 649-658.

Rajala, P. \& Westerling, B. 1980: Responses of corral-fed reindeer to some commonly-used wood fertilizers in Finland. In E. Reimers et al. (eds.): Proceedings of the Second International Reindeer/Caribou Symposium, Røros, Norway, 1979. Pp. 240-243. Trondheim: Direktorat for Vilt og Ferskvannsfisk (Directorate of Game and Freshwater Fish).

Raynolds, M. K. \& Felix, N. A. 1989: Airphoto analysis of winter seismic disturbance in northeastern Alaska. Arctic 42, 362-367.

Roby, D. D. 1978: Behavioral pattern of barren-ground caribou of the Central Arctic Herd adjacent to the Trans-Alaska oil pipeline. M.S. thesis, University of Alaska Fairbanks.

Rominger, E. M., Allen-Johnson, L. \& Oldemeyer, J. L. 1994: Arboreal lichen in uncut and partially cut subalpine fir stands in woodland caribou habitat, northern Idaho and southeastern British Columbia. For. Ecol. Manage. 70(I-3), 195-202.

Russell, D. E. \& Martell, A. M. 1985: Influence of the Dempster Highway on the activity of the Porcupine Caribou Herd. In A. M. Martell \& D. E. Russell (eds.): Caribou and human activity. Proceedings of the First North American Caribou Workshop, Whitehorse, Y.T., 1983. Pp. 22-26. Ottawa: Canadian Wildlife Service.

Shideler, R. T. 1986: Impacts of human developments and land use on caribou: a literature review. Vol. 2. Impacts of oil and gas development on the Central Arctic Herd. Tech. Rep. 86-3. Alaska Dept. Fish and Game, Habitat Div.

Shideler R. T., Robus J. F., Winters, J. F. \& Kuwada, M. 1986: Impacts of human developments and land use on caribou: $a$ literature review. Vol. 1 . A worldwide perspective. Tech. Rep. 86-2. Alaska Dept. Fish \& Game, Habitat Div.

Shtil'mark, F. R. 1984: Ecological niche of wild reindeer in the taiga in relation to human influence on forest landscapes. In E. E. Syroechovskii (ed.): Wild reindeer of the Soviet Union. Proceedings of the First Interdepartmental Conference on Preservation and Rational Utilization of Wild Reindeer, 1974. Pp. 95-98. New Delhi: Amerind Publ.

Shtil'mark, F. R. \& Azarov, V. I. 1984: Wild reindeer of the
Konda River basin. In E. E. Syroechovskii (ed.): Wild reindeer of the Soviet Union. Proceedings of the First Interdepartmental Conference on Preservation and Rational Utilization of Wild Reindeer, 1974. Pp. 180-182. New Delhi: Amerind Pubi.

Skoog, R. O. 1968: Ecology of the caribou (Rangifer tarandus granti) in Alaska. Ph.D. diss., University of California Berkeley. Ann Arbor, MI, University Microfilms, Inc.

Skrobov, V. D. 1984: Human intervention and wild reindeer. In E. E. Syroechovskii (ed.): Wild reindeer of the Soviet Union. Proceedings of the First Interdepartmental Conference on Preservation and Rational Utilization of Wild Reindeer, 1974. Pp. 90-94. New Delhi: Amerind Publ.

Smith, W. T. 1988: Effects of hunting with the use of snowmachines on movements of Western Arctic Herd caribou, Seward Peninsula, Alaska. Proceedings of the Third North American Caribou Workshop. Wildl. Tech. Bull. 8, 211-219. Alaska Dept. of Fish and Game.

Smith, W. T. \& Cameron, R. D. 1983: Responses of caribou to industrial development on Alaska's Arctic Slope. Acta Zool. Fenn. 175, 43-45.

Smith, W. T., Cameron, R. D. \& Reed, D. J. 1994: Distribution and movements of caribou in relation to roads and pipelines, Kuparuk Development Area, 1978-90. Wildl. Tech. Bull. 12. Alaska Dept. of Fish and Game.

Sokol'skii, S. M. 1984: Wild reindeer of the upper reaches of the Pechora River. In E. E. Syroechovskii (ed.): Wild reindeer of the Soviet Union. Proceedings of the First Interdepartmental Conference on Preservation and Rational Utilization of Wild Reindeer, 1974. Pp. 172-175. New Delhi: Amerind Publ.

Spaling, H. \& Smit, B. 1993: Cumulative environmental change: conceptual frameworks, evaluation approaches, and institutional perspectives. Environ. Manage. 17, 587-600.

Spaling, H. \& Smit, B. 1995: A conceptual model of cumulative environmental effects of agricultural land drainage. Agric. Ecosyst. Environ. 53, 99-108.

Stevenson, S. K. 1990: Managing second-growth forests as caribou habitat. Rangifer, Spec. Issue 3, 139-144.

Surrendi, D. C. \& DeBock, E. A. 1976: Seasonal distribution, population, status and behaviour of the Porcupine Caribou Herd. Edmonton: Canadian Wildlife Service, Western and Northern Region.

Syroechkovski, E. E. 1984: Overview of the problem of wild reindeer in the Soviet Union. In E. E. Syroechovskii (ed.): Wild reindeer of the Soviet Union. Proceedings of the First Interdepartmental Conference on Preservation and Rational Utilization of Wild Reindeer, 1974. Pp. 6-44. New Delhi: Amerind Publ.

Syroechkovski, E. E. 1990: Reindeer in the USSR: problems of protection and rational use. Rangifer, Spec. Issue 3, 423-432.

Tracy, D. M. 1977: Reactions of wildlife to human activity along Mount McKinley National Park road. M.S. thesis, University of Alaska.

Truett, J. C., Senner, R. G. B., Kertell, K., Rodrigues, R. \& Pollard, R. H. 1994: Wildlife responses to small-scale disturbances in Arctic tundra. Wildl. Soc. Bull. 22, 317-324.

Tyler, N. J. C. 1991: Short-term behavioural responses of Svalbard reindeer Rangifer tarandus platyrhynchus to direct provocation by a snowmobile. Biol. Conserv. 56, 179-194.

Valkenburg, P. \& Davis, J. L. 1985: The reaction of caribou to aircraft: a comparison of two herds. In A. M. Martell \& D. E. Russell (eds): Caribou and human activity. Proceedings of the First North American Caribou Workshop, Whitehorse, Y.T., 1983. Pp. 7-9. Ottawa: Canadian Wildlife Service. 
Villma. L. 1975: Plenary session: potential impact of accelerated northern development on caribou and reindeer populations and ecology - the Scandinavian viewpoint. In Iuick et al. (eds.): Proceedings of the First International Reindeer Caribou Symposiam. Fairbanks, Alaska, 1972. Biol. Pap. Univ. Alaska, Spec. Rep. 1. 4-9.

Vistness, I. 1999: Avoidance of cabins and power transmission lines by semidomesticated reindeer during calving. M.S. thesis. Agricultural University of Norway.

Walsh, N. E., Griffith. B. \& McCabe. T. R. 1995: Use of a stochastic population model to predict growth of the Porcupine Caribou Herd. J. Wildl. Manage. 59, 262-272.

White, R. G. 1983: Foraging pattems and their multiplier effects on productivity of northern ungulates. Oikos 40, 377-384
White, R. G. 1992: Nutrition in relation to season. lactation, and growth of north temperate deer. In R. D. Brown (ed.): The biology of deer. Pp. 407-417. New York: Springer.

Whitten, K. R. \& Cameron, R. D. 1983: Movements of collared caribou, Rangifer tarandus, in relation to petroleum development on the Arctic Slope of Alaska. Can. Field-Nat. 97. 143-146.

Whitten, K. R. \& Cameron, R. D. 1985: Distribution of caribou calving in relation to the Prudhoe Bay oil field. In A. M. Martell \& D. E. Russell (eds): Caribou and human acrivity. Proceedings of the First North American Caribou Workshop, Whitehorse, Y.T., 1983. Pp. 35-39. Ottawa: Canadian Wildlife Service. 


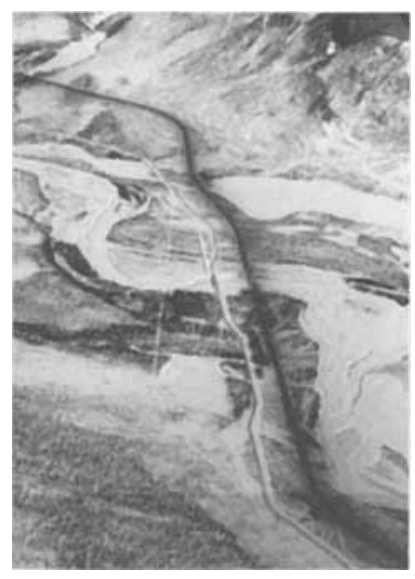

Dust travels up to $1 \mathrm{~km}$ from the Haul Road in northern Alaska, spring 1994. It settles on the snow surface where it has several effects, including reducing albedo (surface reflectance) leading to early melting in springtime and excessive thawing of frozen ground. Photo: C. Gubala.

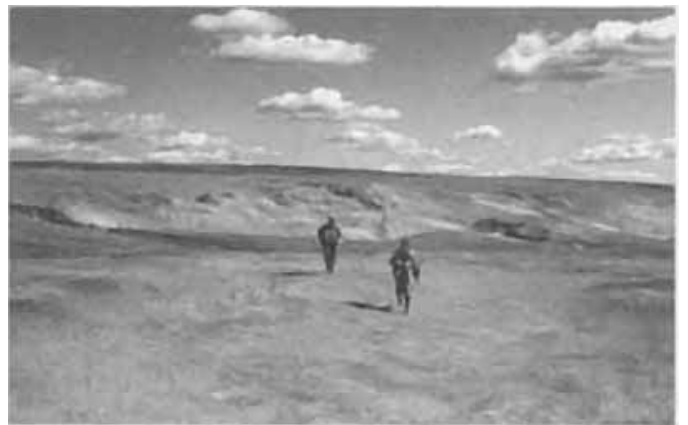

Such sites as this abandoned gas test well, central Yamal Peninsula, June 1993, are widespread throughout Yamal and are problematic for several reasons: (i) slow revegetation due to dry, nutrient-poor and unstable sand surfaces; (ii) deflation of sand/ dust to the surrounding area, resulting in the rapid burial of tundra vegetation; (iii) toxic drilling muds often left on the surface; and (iv) rusted metal, broken glass and other trash which can injure reindeer's hooves. Photo: B. Forbes.

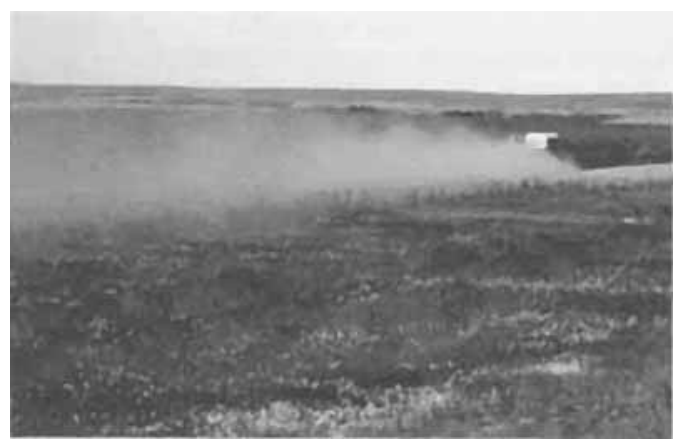

Relatively alkaline ( $\mathrm{pH}$ ca. 8.0) road dust, as seen here on southern Yamal, July 1995, alters substrate chemistry and patterns of nutrient content in vascular and non-vascular plants which serve as reindeer forage. Road dust has also been reported to significantly reduce the production of cloudberry (Rubus chamaemorus) fruits and mushrooms in the mires adjoining the main transport corridor on southern Yamal (see Klein, this issue). Photo: B. Forbes.

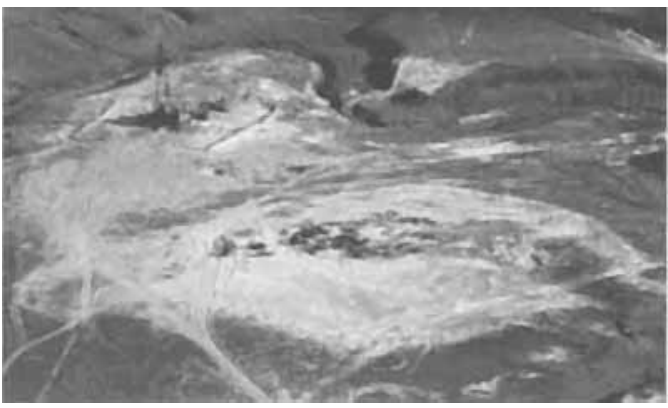

In the vast Yamal region, industrial disturbance, such as sand quarrying (seen here July 1995), seems minor. Nonetheless, as Nenets reindeer herders point out, developers take the best lands - higher, drier ground - for infrastructure. In an area as flat as Yamal, dominated by mires and lakes, this puts unsustainable pressure on the remaining relatively high ground, exploited by reindeer for insect relief in summer. The end result is that extensive grazing by the reindeer themselves appears to be negatively affecting pastures. Photo: B. Forbes.

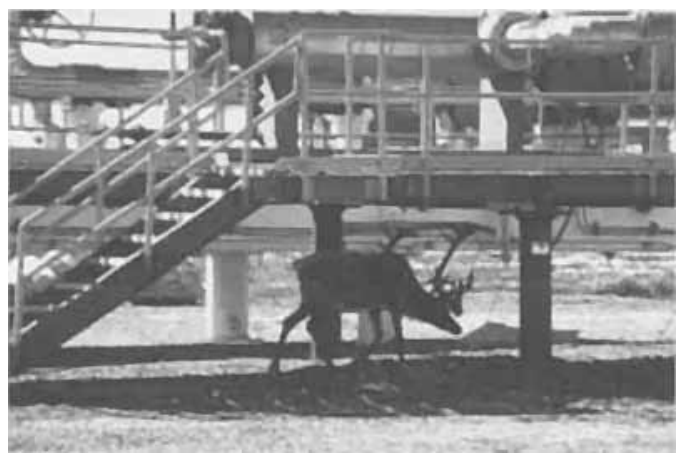

A Central Arctic Herd caribou bull escapes the summer heat in the shade of an oil processing facility at Prudhoe Bay, Alaska. While caribou cows generally avoid oil fields during calving. animals commonly utilize building shade and raised gravel pads for insect and heat relief in the summer. Photo: G. Kofinas.

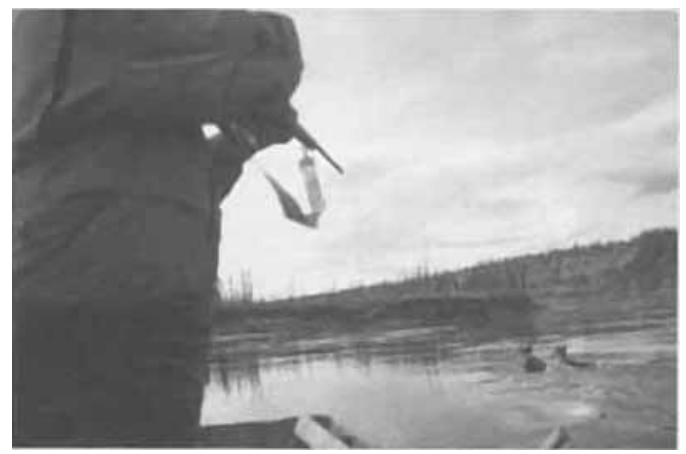

Vuntut Gwitchin hunter, Lawrence Lord of Old Crow, Yukon, takes aim on the Porcupine River. Hunting from boats is common for those communities intercepting caribou at river crossings, and typically results in a more efficient, less wasteful harvest. Photo: G. Kofinas. 